always happy in its English, nor is the writer quite so careful in expressing his own meaning.

It is ungenerous to niggle at two such useful books; nevertheless some faults should be pointed out. There is no harm in confining 'Animals' in the title of the first to its pop sense as 'Mammals', but page 22 is a little late to tell us that this is what the book is going to do. The distribution maps attached to the coloured pictures are an excellent idea, but in some cases the contrast with the caption is absurd. For example, the caption to the aye-aye says that 'some score or 20' may survive, nine individuals on one islet; the map shows no islet but five other locations which at this rate would have two point something animals each. In the Ziswiler book the Appendix list of species in danger is badly set out; to print English and Latin names in the same type is confusing. The selection of species is highly arbitrary-South American forms are much under-represented for example. And on what evidence are the wild horse and wild camel alleged to be subject to slaughter for meat and fat?

Both books display the giant panda on their dust covers. Fitter rightly notes in his text that it is not in peril, but Ziswiler includes it in his Appendix as among the 'most gravely threatened' although he has to leave the column of dangers to it completely blank. Actually, of course, it is rare, but neither extinct nor vanishing. On the other hand neither author says much or anything about the African leopard and the Indian tiger and the common Indian monkeys - nor does Ziswiler, who should, even mention crocodiles or any alligator but the Chinese all of which are certainly doomed, and within a very few years, if the toll of the laboratories and the fur and skin trade are not checked. At what exact figure would it have been right to begin to be anxious about the passenger pigeon and the western 'buffalo'? Surely an animal should qualify for the label 'vanishing' on the basis of its rate of decline, rather than by being stably rare or of a picturesque appearance.

The major weakness I find in these two otherwise excellent books is common to many others on the subject. Neither, in its examination of causes and remedies, really faces up to the fact that conservation is as much a responsibility of our own sophisticated populations as of those of the undeveloped territories in which the animals actually live. There is too much glib talk of policing countries far away when what we ought to be doing is making the dealing in vanishing animals and the wearing of their products crimes punishable in our own. Also, if we want to ask hungry locals not to kill walking bags of protein that pass by their villages, we must be ready to tax ourselves for aid programmes before we well-fed peoples claim restraint from those who are less well-off.

IVOR MONTAGU

The Apes by Vernon Reynolds. Cassell, 63s.

\title{
A Handbook of Living Primates by J. R. Napier and P. H. Napier. Academic Press, 126s.
}

The study of the primates is a growing point in biology, for their nearness to man, who has not always been too keen on recognising his poor relations, throws increasing light on that most important but most neglected of all disciplines, human behaviour. In this connection primates means not archbishops but apes and monkeys, and also marmosets, lemurs, lorises, tarsiers and perhaps tree-shrews (the experts are currently at odds over the relationships of tree shrews). Both books are most valuable contributions.

Dr Reynolds, one of our leading students of animal behaviour who has spent a great deal of time with chimpanzees in the field, distils from his experience an admirable summary of the natural history of the apes, gorillas, chimpanzees, 
orang-utan and gibbons. No laboratory man could have shown the insight he reveals in his last paragraph, where he points out that our giant urban agglomerations, far from being an unnatural environment for man, are at last the means of freeing him from the small-community restrictions imposed on him by thousands of years of agriculture and returning him to the hunter-gatherer environment in which he evolved. His chapter on conservation also contains many valuable suggestions, especially for enabling zoos, research institutes and other 'consumers' of wild apes to stop their fatal drain on the rapidly diminishing wild stocks.

The Napiers have provided an essential reference book for all who are studying or are in any way interested in the primates as a whole, including the disputed tree-shrews. Besides much general information on the traditional aspects of their biology, there is a summary of the characteristics of each genus, with supplementary taxonomic notes, a complete check-list, special data on macaques, which are the most researched-on primates, and a final section containing useful statistics on such aspects as gestation periods, chromosome numbers, longevity records and comparative weights and dimensions. Their one weakness lies where Vernon Reynolds is so strong, in summarising the enormous amount of new data produced by the present generation of young ethologists who have actually gone out and lived with primates in the wild.

RICHARD FITTER

\section{Lemur Behaviour: A Madagascar Field Study by Alison Jolly. University of Chicago Press, 52s.}

In the last ten years an increasing number of people interested in primate behaviour have moved from the laboratory to the field. More often than not, this entirely welcome development has been motivated by a desire to explain the evolution of human social organisation rather than by curiosity or the pleasures of field work. Alison Jolly shares the ambition to explain away; but this has not prevented her from describing with care and sensitivity the ecology and social behaviour of two species of prosimian, Propithecus verreauxi and Lemur catta. For anyone interested in the evolution of primate behaviour, the lemurs must have seemed promising material since in many ways they appeared primitive. Certainly they are peculiar - which is not perhaps surprising as they have supposedly been isolated on Madagascar for 50 million years. Mrs Jolly found, for example, that the breeding season of Lemur catta is highly restricted and synchronised - which incidentally puts another nail in the coffin of the idea that sex alone keeps primate societies together.

The lemurs' sense of smell is extremely well developed and they produce a number of secretions which seem to be used in social displays. Mrs Jolly became aware of her own limitations while watching what she calls 'scent fights'; in this respect the lemur-watcher is more handicapped than, say, the bird-watcher. Nevertheless there was plenty for Mrs Jolly to look at. The territorial behaviour of Propithecus verreauxi is striking and also a little absurd. One band will defend an area from another band but in doing so will always face away from the centre of their territory. As a result in border skirmishes, rival bands may end up with their backs to each other.

This attractive if somewhat specialised book is marred by an attempt to interpret the observations in terms of recently fashionable ideas which, to my mind, are ill-defined or tautologous. The problems which Mrs Jolly set out to tackle remain elusive, and theorising about the evolution of human behaviour seems emptier than ever. It seems so, however, as a result of the recent field work of which this study is an excellent part.

P. P. G. BATESON 